\title{
«НОВЫЙ МИР» НА КРАЮ ДЕРЕВНИ: РОДОВЫЕ ПОМЕСТЬЯ И СОСЕДИ
}

Community is not just about living together, but about the reasons for doing so.

D.L. Christian

Поселения родовых поместий (экопоселения) возникли в начале 2000-х годов под влиянием серии книг Владимира Мегре «Звенящие кедры России». Обычно они объединяют жителей, интересующихся идеями здорового образа жизни, органического земледелия и зачастую духовными поисками. На сегодняшний день в России насчитывается около 500 поселений в разных регионах, но в первую очередь в Европейской части и на юге страны. Желание построить «новый мир» - это одновременно и отказ от следования преемственности традиционному селу и попытка реконструировать национальный проект и образ жизни «далеких предков». Строителям родовых поместий необходимо создать всю инфраструктуру, договориться с соседями и администрацией, построить дом и придумать способ заработка вне города. Общение с местными жителями не входит в первоочередные задачи переселенцев, часто бывает посредник, который берет на себя контакты с органами власти и сельскими жителями. Приезжие встречают среди местных жителей непонимание и подозрения в сектантстве. Поселенць позиционируют себя миссионерами, просвещающими местную публику. При этом, несмотря на колонизаторский пафос, сколько бы лет переселенць ни прожили в селе, для местных жителей они все равно остаются чужаками и, по сути, не допускаются на общих основаниях к ресурсам села.

Ключевые слова: экопоселения, родовые поместья, город, село, анастасийизы, «Звенящуие кедры России»

Ссылка при цитировании: Андреева Ю.О. «Новый мир» на краю деревни: родовые поместья и соседи // Вестник антропологии, 2022. № 1. С. 104-116.

\footnotetext{
Андреева Юлия Олеговна - к.и.н., младший научный сотрудник отдела этнографии Кавказа, Музей антропологии и этнографии им. Петра Великого (Кунсткамера) РАН (199034 Санкт-Петербург, Университетская наб., 3). Эл. почта: Julia.o.andreeva@gmail.com ORCID https://orcid. org/0000-0002-5704-4034.

* Работа выполнена при поддержке проекта РФФИ № 19-09-00381А «Новая сельскость» в современной России: институты, практики, социальное взаимодействие»
} 
DOI: $10.33876 / 2311-0546 / 2022-1 / 104-116$

(C) J.O. Andreeva

\title{
“THE NEW WORLD" AT THE EDGE OF THE VILLAGE: KIN'S DOMAINS AND THEIR NEIGHBORS
}

\begin{abstract}
Settlements of kin's domains (ecovillages) emerged in the early 2000s under the influence of Vladimir Megre's series of books "The Ringing Cedars of Russia". Usually, they unite people interested in healthy lifestyles, organic farming, and spiritual quests. Today there are about 500 settlements in different regions, but primarily in the European part and the south of Russia. The desire to build a "new world" is both a rejection of the traditional village and an attempt to reconstruct the national project and way of life of "distant ancestors". Constructing a kin's domain requires creating the entire infrastructure, negotiating with the neighbors and the administration, building a house, and figuring out a way to earn money outside the city. Communicating with local residents is not a priority for newcomers; there is often an intermediary who takes care of contacts with authorities and villagers. The newcomers face misunderstanding and suspicion of sectarianism among the locals. Settlers position themselves as missionaries enlightening the local public. At the same time, despite their colonialist pathos, no matter how many years settlers have lived in the village, they remain strangers to the locals and, in fact, are not allowed to access the village's resources on general grounds.
\end{abstract}

Keywords: ecovillages, kin's domains, urbanism, rurality, Anastasians, "Ringing Cedars of Russia"

For Citation: Andreeva, J.O. 2022. "The New World" at the Edge of the Village: Kin's Domains and Their Neighbors. Herald of Anthropology (Vestnik Antropologii) 1: 104-116.

Author Info: Andreeva, Julia O. - PhD, Junior Researcher, Caucasus Department, Peter the Great Museum of Anthropology and Ethnography (Kunstkamera), Russian Academy of Sciences (University Emb., 3, St. Petersburg, 199034, Russia). https:// orcid.org/0000-0002-5704-4034. E-mail: Julia.o.andreeva@gmail.com

Funding: The study was carried out with the financial support of the Russian Foundation for Basic Research, scientific project No. 19-09-00381A

Сегодня привычная исследователям дихотомия города и села уже не так значима, как ранее. Социальные географы обращают внимание на то, что город и село включаются в единую форму социальной организации - сельско-городского континуума, где совмещаются оба «мира» (Нефедова и др. 2015: 62-63). Любые сообщества так или иначе охватываются понятиями «глобального города» и «новой географии центральности», для которых характерна транснациональная экономика, «гипермобильность, глобальная коммуникация, нейтрализация места и расстояния» (Sassen 2018: 11-12). Современное село включает в себя и дачников, и агрохолдинги, и фермеров, и отходников. Один из вариантов сельского образа жизни, ставший популяр- 
ным в последние годы - это «родовое поместье». Так называют участок земли не менее гектара, на котором проживает одна семья. Группа таких поместий образует поселение: оно может быть оформлено как некоммерческое партнерство или существовать исключительно в воображении отдельных жителей, находящихся друг от друга на расстоянии нескольких километров.

Поселения родовых поместий (экопоселения) создаются с начала 2000-х годов в разных регионах России и ближнего зарубежья. Согласно сайту «Поселения.ру», на сегодняшний день насчитывается более 500 поселений родовых поместий и почти 6 тысяч проживающих в них человек. Конечно, многие из этих проектов находятся в зачаточном состоянии, однако цифра говорит о распространенности явления (Статистика количества поселений 2021). Идея необходимости переезда в родовые поместья была описана в серии книг Владимира Мегре «Звенящие кедры России» в начале 2000-х годов, где главная героиня сибирская отшельница Анастасия предлагает альтернативный способ процветания страны и мира (Андреева 2015). Позднее такие поселения стали соотносить с глобальным движением экопоселений (Global Ecovillage Network), к которому присоединяется большое разнообразие «идейных сообществ» (intentional communities) со всего мира.

Статья основана на полевых материалах автора, собранных в поселениях родовых поместий на Северо-Западе России и на встречах поселенцев в Санкт-Петербурге в 2009-2019 гг. Также используются вторичные источники - записи в блогах и соцсетях. Поскольку каждое поселение во многом творческий и экспериментальный продукт, а единых правил его оформления нет ни в законодательстве, ни среди единомышленников, то я не генерализирую мои наблюдения на все поселения анастасийцев. В то же время многие похожие ситуации описываются в Интернете и применительно к другим поселениям, где я не была. Мой взгляд представляет в первую очередь позицию поселенцев, я всегда интересовалась мнением местных жителей и беседовала с ними, но большинство «голосов» коренного населения все же слышны через уста приезжих.

Поселения родовых поместий обычно объединяют жителей, интересующихся идеями здорового образа жизни, органического земледелия и зачастую духовными поисками. Проект строится не только на создании чего-то нового, но и на идеологии возвращения к земле, природе, к своим истокам. Поместья представляют собой набор построек часто экспериментальных форм (круглые, овальные, пятиугольные) и из необычных материалов (саман, песок), хаотично разбросанных на больших расстояниях друг от друга. Такие поселения располагаются как рядом с традиционной деревней или частично внутри нее, так и в чистом поле вдали от всех населенных пунктов.

Географы задаются важным методологическим вопросом, что из себя представляет переезд горожан в сельскую глубинку - «уход за пределы города» или «это эволюция города, новая ипостась, реализующая себя в иной географической среде?» (Нефедова и др. 2015: 64). Меня же интересуют то, как такие коллективные проекты переселения взаимодействуют с (казалось бы) традиционной деревней. Как строится коммуникация поселенцев с коренными жителями? Есть ли попытки вписаться в локальное сообщество? Значимы ли для переселенцев само по себе село и локальность с его культурным капиталом? Круг вопросов очень широк и требует обстоятельного изучения, здесь же я попробую не столько ответить на них, сколько поделиться своими наблюдениями столкновения «коренных» и «пришлых». 


\section{Новый мир}

Жителям родовых поместий, как правило, важно подчеркнуть отличие их проекта от более привычного для окружающих коттеджного поселка - территориальное (большой участок земли), функциональное (как основное место жительства) и идеологическое («родовое гнездо», новая «осознанность», вегетарианство и т.п.). Строители родовых поместий противопоставляют свой проект и даче, и деревне. Если смотреть или слушать рассказы жителей о поселении, может создаться впечатление как будто и нет никаких соседей-сельчан: они редко упоминаются и почти никогда не встречаются в авторепрезентации поселений. Разумеется, тема села всплывает, в первую очередь, при упоминании местной администрации и оформления земли ${ }^{1}$.

Желание построить «новый мир» ${ }^{2}$ - это одновременно и отказ от следования преемственности традиционному селу и попытка реконструировать национальный проект и образ жизни «далеких предков» ${ }^{3}$. Часто поселения оформляются на земле сельскохозяйственного назначения, поэтому они оторваны от жизни близлежащих населенных пунктов, даже если соседствуют с ними. Строители поместий полны энтузиазма и запала креативности - им необходимо создать всю инфраструктуру практически с нуля (дорога, электричество, водоснабжение, школа), договориться с соседями и администрацией, построить дом и придумать способ заработка вне города. Для этого нужно овладеть многими навыками и знаниями. Поселенцы противопоставляют домодерную (сельскую) универсальность и узкоспециализированные знания горожанина, неспособного выжить в кризисных ситуациях. Работа над собой, которую необходимо проделать при смене места жительства, часто демонстрируется в медийном поле. «Помещики» ведут блоги и рассказывают, как переехать в свое родовое поместье, как решиться на такой нестандартный шаг и как оставаться на избранной дорожке. В таких нарративах «обращения» переезд почти всегда является поворотной точкой биографии (Мельникова 2020).

Общение с местными жителями не входит в первоочередные задачи переселенцев, часто бывает посредник (или рабочая группа), который берет на себя контакты с администрацией и сельскими жителями. Иногда в рамках поселения обсуждается общая стратегия, как позиционировать себя внешнему миру, что лучше говорить и о чем лучше молчать. Но жители поселения могут ей не следовать или такой единой политики может и не быть.

Соседство с селом позволяет пользоваться готовой школой, почтой, магазинами. Риторика переезда строится не столько на том, как вписаться в местное сообщество, а как создать собственную автономную инфраструктуру. Такое позиционирование связано в том числе с тем, что поселения создаются в или поблизости от вымирающих деревень, на землях, не пользующихся спросом и не самых пригодных для сельского хозяйства ${ }^{4}$. Они добровольно заперты в рамках своего комьюнити. Ис-

${ }^{1}$ О юридическом оформлении родовых поселений см. (Позаненко 2016).*

${ }^{2}$ Так называется одно из поселений, расположенное в Республике Мордовия.

3 Здесь могут быть варианты, какое именно прошлое предполагается восстанавливать - славянское или ведрусское (ведическое). О дискуссиях, посвященных народным традициям, см. (Андреева 2012).

${ }^{4}$ В данном случае имеются в виду поселения Северо-Запада и Центральной России. В черноземных регионах, в первую очередь в Краснодарском крае и Ростовской области ситуация будет совсем иной. 
следователь поселений О.М. Аничкова подтверждает, что выходцы из городов не испытывают никакого желания «обрастать с деревенскими жителями соседскими связями, кооперироваться в работе, вступать в другие формы социального взаимодействия. Они скорее вынуждены выстраивать коммуникацию с местным сообществом, нежели идут на это искренне и охотно» (Аничкова 2020).

Помимо обособления себя от сельчан, для большинства поселенцев характерна условность переезда из города в загородное жилье. Новые сельчане во многом лишь физически находятся в деревне, тогда как их окружение, работа, привычки и бытовые практики остаются напрямую связаны с городом. Большинство жителей поселений часто там бывают: кто-то работает дистанционно в городе, у других дети сдают там школьные экзамены, третьи продают излишки сельхозпродукции и т.п. У многих основной источник дохода - сдача в аренду городского жилья. Таким образом, почти всегда это неокончательный переезд из города в село, жизнь нередко протекает между двумя точками. В отличие от коренных сельских жителей, у «помещиков» есть выбор, они могут зимовать в поместье, а если будет скучно или холодно могут вернуться в город.

Поселенцы декларируют, что отличаются от сельчан целеполаганием: они возвращаются на землю, но руководствуются в первую очередь «осознанностью» в тех практиках, которые характерны в том числе и для сельских жителей. Например, ограничивают себя в питании, транспорте, одежде, технике не из-за бедности и невозможности себе это позволить, а исходя из сознательного выбора - нанесения меньшего вреда окружающей среде. В частности, они отказываются от неэкологичных или привозных продуктов, покупки ненужных вещей, осуществляют обмен одеждой, передвигаются на велосипеде или совместно используют автомобиль. Однако все эти практики на самом деле только начинают проникать в поселения, и вопросы раздельного сбора мусора и глобального потепления волнуют только ограниченные круги активистов. Жители поместий также часто отмечают деревенский алкоголизм и пассивность, различия в «скорости мысли» и «чистоте помыслов». Вербальная благодарность лесу, воздуху, воде, земле покажется странной человеку, выросшему в деревне, но будет естественной для «помещика».

Как правило, большинство жителей поселений - вегетарианцы, не курят, не используют органические удобрения, стараются минимизировать использование любых химических средств, поддерживают все «натуральное» (продукты, одежду, косметику), не делают прививки. Но все эти черты, в общем, необязательны, они могут быть нигде не прописаны, а восприниматься поселенцами как само собой разумеющиеся. В то же время поселение отнюдь не гомогенно, внутри него почти всегда есть разные подгруппы, у которых есть свои претензии друг к другу, например, постоянно проживающие и дачники, последователи идей Анастасии и менее идеологизированные жители, практики и «хороводники».

Экопоселения - это не коммунитарный проект, но многое в них направлено на создание «единства»: вече с идеей единогласного принятия решений, собрания, совместная работа на общих территориях, помощь соседям в строительстве, сбор денег в кризисных ситуациях (пожары, болезни и т.п.). Через коллективные действия, личный вклад в общее дело предполагается преодолеть эгоизм, который считается характерной чертой именно городского человека (ПМА 2009, муж., ок. 45 лет). Философ Зигмунт Бауман, описывая общество позднего модерна, подчеркивал его противоречивость и «текучесть»: с одной стороны, индивиды гораздо больше избегают 
общих мест («не разговаривайте с незнакомцами»), а, с другой стороны, коллективные инициативы вроде коммун воспринимаются вовсе не как регресс и экзотичный феномен, а вполне закономерный процесс, «рациональная реакция на подлинный кризис «общественного пространства» (Бауман 2008: 117).

\section{Родовые поместья: взгляд из села}

Дихотомия город-село крайне жива в дискурсе обеих сторон. Для сельчан город притягательное место, пространство возможностей и благ, даже если они не хотят туда переезжать. Село же ассоциируется с отсталостью и нецивилизованностью. Жители родовых поместий демонизируют город: город - это «система», место духовного и физического нездоровья, территория зависимости, несвободы и порабощения человеческого ума. Высшее же звено в их иерархии занимает не традиционная деревня, тоже погрязшая в плену городских иллюзий, а дикая природа, утопическая ведическая деревня и вновь создаваемые поселки. В воображении переселенцев жизнь на земле дает безопасность и гарантии обеспечения питанием и другими необходимыми ресурсами. Однако они признают, что села пустеют и жители, находясь в плену городских иллюзий, покидают насиженные места в поисках лучшей жизни и заработка:

«А в городе просто больше возможностей. Ты в прямом смысле слова, ну, условно, можешь ничего не делать, а деньги зарабатывать. В прямом смысле не делать, потому что, условно, купи-продай это не делать. Это просто [неразб.]. А именно делать, что-то делать, тут... Сезонные работы, я же говорю, дома построить, там дома поставить, ремонты какие-то, помочь чем-то» (ПМА 2019, муж., 42 года).

Приезжие встречают среди местных жителей в первую очередь непонимание: в них видят оторванных от реальности чудаков, оставивших из странных соображений комфортную городскую жизнь. Местные оценивают по принципу: «мужик сказал - мужик сделал», и воспринимают активную экспериментальную деятельность поселенцев, у большинства из которых слова расходятся с делами, как пустую болтовню (ПМА 2019, муж., ок. 40 лет).

Кроме того, анастасийцев подозревают в корыстных целях, захвате территории и намеренном вытеснении местных. Новых соседей нередко называют сектантами: «Там, в тупике, где дорога заканчивается, сектанты. Мы туда не ходим»; «А вы куда едете? А, понятно, это где сектанты...»; «Вы хотите в поселение поехать? Осторожно! Это же секта!» (Аничкова 2018). Даже несмотря на выбранную стратегию поселенцев их все равно считают приверженцами каких-то непонятных «сект» (Позаненко 2016: 146).

Мои собеседники в поместьях, разумеется, тоже не раз сталкивались с обвинениями их в сектантстве, упоминали об осторожных расспросах местных: «Она говорит: “Скажите, пожалуйста, а вы какой веры все тут?”. Я говорю: “Я не знаю, я не спрашивала». Она такая... все, больше ничего не спросила, такая: «хорошие вь люди!' [смеется]. То есть, в ичелом нас местные, я бы даже сказала, любят. А что им нас не любить? Люди живые. С детьми» (ПМА 2019, жен., около 40 лет).

Как видно из вышеприведенной цитаты, наряду с настороженностью встречаются и ситуации, когда деревенские жители рады оживлению села. Они отмечают навыки и знания приезжих, многодетные семьи и активность в культурной жизни. Например, пожилая женщина в Ленобласти отзывалась о своих соседях-поселенцах 
как о «парнях хороших, рукастых», которые все умеют делать по хозяйству (ПМА 2017, жен., около 70 лет). Представитель администрации Псковской области приезжала на круглый стол в Санкт-Петербурге, посвященный экопоселениям, и благодарила приезжих за то, что они спасли вымирающую деревню (ПМА 2009, жен., около 45 лет). Когда поселения организуются бывшими сельчанами, возвращающимися на свою малую родину (как например и было в последнем случае), они обычно встречают более теплый прием и понимание.

Артемий Позаненко отмечает, что «у экопоселенческого (и в особенности анастасийского) движения есть любопытное свойство, заключающееся в заметном разрастании без сопутствующей этому огласки. В районах, где расположены поселения, местные жители о них знают, но никто и не подозревает, что это не частный случай переезда чудаковатых горожан, а вполне распространенное явление» (Позаненко 2016: 149). Такое незнание или крайне поверхностное знание об общероссийском проекте поселений, книгах Владимира Мегре и инициативах закона о родовых поместьях заметно и в разговоре с местными жителями.

\section{Поселение родовых поместий и село: взаимодействие}

Если поселение существует уже несколько лет, то его жители нередко говорят о том, что они ассимилировались и прижились. Их ощущение и позиционирование не всегда совпадает с восприятием локального сообщества, которое привыкло к ним, но продолжает видеть в них чужаков. Атмосфера недоверия необязательно выливается в открытые конфликты, но неприятные казусы, вроде поджигания травы на общих полях, могут периодически случаться.

Есть и успешные попытки сотрудничества с местными жителями. Экопоселенцы предоставляют им возможность заработка - нанимают сельских мужчин на ремонт, строительство и сельскохозяйственные работы, покупают у них молочные продукты (если кто-то держит животных), овощи и фрукты. Вовлечение местных жителей в отдельные проекты сталкивается с ограничениями, например, деревенские женщины готовы заниматься уборкой и мытьем посуды на массовых мероприятиях, но отказываются работать официантками при организации кейтеринга. Поселенцы жалуются, что на их инициативы в селе нет работников, им приходится привозить свои кадры из города.

Приезжие могут быть трудоустроены в рамках села и даже занимать руководящие посты в местных социальных службах. В таких случаях они волей-неволей регулярно сталкиваются с коренными жителями и пользуются поддержкой сельской верхушки. Присутствие представителя от родовых поместий в органах местной власти хотя и исключительная ситуация ${ }^{1}$, но встречается на практике:

«Основное, что она сделала, это ключевое. Она расположила администрациию к нам. Все. Это самое основное. <... Это ключевое. В этих всех вопроcax. В любых, ну, вообще, в земельных [неразб.]. Когда администрация относится лояльно к тем, кто здесь живет. Потому что у нас есть примеры того, когда ... Есть поселение, оно, мягко говоря, с администрачией вот так, находится в контрах, да, администрация никак им не помогает, ни в каких вопросах, и все» (ПМА 2019, муж., 42 года).

\footnotetext{
${ }^{1}$ А.А. Позаненко описывает, что он тоже только однажды сталкивался с тем, что житель родового поместья был представителем власти - депутатом сельского поселения (Позаненко 2016: 147).
} 
Но иногда судебные тяжбы продолжаются более десятка лет, и поселенцы признают свое бессилие найти контакт в локальном сообществе. Конфликты с местными властями часто выливаются в претензии нецелевого использования земли и постановления о сносе домов. Дело в том, что почти все поселения родовых поместий не имеют статуса населенных пунктов, и созданные ими постройки на земле сельскохозяйственного назначения во многих случаях нелегальны.

Помимо вопросов, связанных с оформлением земли и обустройством инфраструктуры, другое место, где поселенцы сталкиваются с «системой», это школа. Почти каждое поселение мечтает создать свою школу с комфортным обучением и использованием альтернативных педагогических методик (Монтессори, Вальдорфа, Щетинина), но полноценно это получается крайне редко, а в успешных случаях действует только начальная школа (Ожиганова 2015: 277-278). Обычная педагогическая система не устраивает идеологическими моментами, дисциплиной, социальным окружением, поэтому некоторые родители переводят детей на домашнее обучение. Тем самым поддерживается оторванность приезжих переселенцев от сельского населения. Бывает и так, что ребенка со временем все равно отдают в ближайшую школу, признавая, что ему не хватает общения со сверстниками и регулярных занятий.

\section{Поселенцы как миссионеры}

Отношение к местным может быть как полностью безразличным, так и нередко покровительственным. Такая позиция протекционизма заметна и на коллективных встречах жителей поселений. Например, представительница крымского поселения говорила о том, что их цель состоит в том, чтобы весь Крым стал одним поселением. Она предлагала не отделять себя от общества, создать образ «не быть другими» и нести его всем окружающим, показать всем, что «оказывается, мы не особенные, анастасиевцы, вокруг все люди тоже с этой идеей, просто они ее не до конца могут оформить в слова, мысли и действия. Им нужно помочь» (Презентация поселений 2021).

В нарративах поселенцев агентность присуща именно им, они отмечают инертность и безынициативность жителей близлежащих деревень. Иногда сельчане подключаются к таким мероприятиям, как строительство дорог, которой они пользуются сами (Демидова 2020), или борьба с вырубками, но чаще всего все проекты ведут приезжие.

Анастасийцы даже могут позиционировать себя демиургами - они принесли свет, знания и даже открыли местным жителям плюсы жизни на селе. Они выступают своеобразными миссионерами, просвещающие местную публику и иногда чувствуя за нее свою ответственность:

«Ну да, вообще отношения у нас нормальные. Может быть, в начале было какое-то ну недоверие, в плане ну вот что все же... все же едут в город, а вы из города. Но это достаточно быстро уило, посмотрев на нас, на наш образ жизни. И даже я бы сказала, что они сами как будто бы немножко воспряли, потому что ну такое было ощущение, что у них вот самоуважение низковатое было такое вот и самоосознание. А когда мы ходим и нахваливаем, так сказать, здесь деревенскую жизнь, и у них получается, что: «Да, мы недурно тут живем!» $<\ldots>$ И вот в той деревне я дружу уже почти с самого начала, как-то там познакомились, и дружу с одной семьей. И, естественно, там муж тракторист, все это выпивающий, не... не пья... не совсем вот не алкаш, но так. И вот они 
тоже как-то так жили: ну деревня, ну вот все вот да... поели и день прошел, ну он на охоту сходил, вот мы грибочков набрали. Вот за эти годы, что мы общаемся, у них даже на дом по-другому ... ну дом по-другому стал выглядеть. У них как будто жизнь какая-то вот в глазах зажглась. < .. > Думаю, интересно, а я вот с ними... я-то не опускаюсь на этот уровень? Нет, ни фига, это они к нам подн... Ну, не к нам, мне тоже не хочется говорить, что мы такие... Но у них действительно... Они все умные и хорошие люди и чаще всего гораздо чище, чем городские. Но вот их действительно, вот это вот, какое-то отсутствие самоуважения, которое у них сейчас возвращается) (ПМА 2019, жен., 51 год).

В данном случае моя собеседница, хоть и делает множество ремарок и отступлений, но вольно или невольно пытается донести мысль, что с их приходом жизнь окружения сильно изменилась, что именно горожане модернизировали и принесли жизнь в эту умирающую и поникшую деревню. Метафора неоколониализма, где пришлые горожане выступают в роли колонизаторов, показывающих коренным, как правильно жить и определяющих за них их интересы и потребности, позволяет охарактеризовать их публичную репрезентацию. Сельчане, в свою очередь, разделяют предлагаемые иерархии и воспринимают жизнь в городе если не как образцовую, то часто как более «высокую», дающую больше возможностей. Со стороны приезжих нет ни эксплуатации, ни политического доминирования, однако остается культурная дистанция. К.В. Аверкиева и Т.Г. Нефедова описывали пример дачной «колонизации», когда столичное население фактически захватило большую часть деревенских домов и внесло значительные изменения в жизнь увядающей глубинки (2016). Приезжие дают местным возможность заработать, привносят новые стандарты благоустройства, но и требуют инфраструктурных вложений от сельской администрации (Аверкиева, Нефедова 2016: 121-122).

У местных жителей, как и у субалтернов, намного меньше возможностей быть видимыми в поле Интернета и подать там свой голос. Они оказываются представлены «большому миру», даже если их участие полностью игнорируется, глазами бывших горожан - через блоги и социальные сети. Конечно, они могут быть не в курсе такой публичности родного края, и она никак не задевает их в ежедневной рутине, но в любом случае их позиция в этом поле остается безгласной.

В классическом колониализме между метрополией и колонией существовали отчетливые расовые, этнические и лингвистические отличия. Модель «внутренней колонизации», где «низшие классы» нередко воспринимались как «свои чужие» (domestic others), а элиты брали на себя «цивилизаторскую» миссию, применяется в исследованиях по отношению к России (Манчестер 2012: 311). Деревенская община была объектом экзотики для русских романтиков-интеллектуалов, собиравших фольклор, они «воспринимали внегородское пространство не только как «забытое свое», но и как «чужое» (Эткинд и др. 2012: 15).

При этом, несмотря на колонизаторский пафос, сколько бы лет переселенцы ни прожили в селе, для местных жителей они все равно остаются чужаками и, по сути, не допускаются на общих основаниях к ресурсам села. «Сами жители деревень не воспринимают приехавших, с которыми бок о бок прожили двадцать-тридцать лет, как своих. Для них они все еще чужие. И для их детей - людей уже среднего возраста - тоже, ведь им с детства об этом повторяли изо дня в день» (Аничкова 2018). Сельчане, да и сельская администрация как раз не слышат голоса приезжих, им не- 
понятны их потребности и их язык, насыщенный ньюэйджерской лексикой и излишним пафосом, и это в том числе приводит к затяжным судебным процессам. Обладая значительными ресурсами «в центре», они исключены из многих локальных процессов и находятся на периферии, во многом завися от решения местной администрации. Получается, что в действительности положение пришлых «захватчиков» крайне зыбкое и изредка, но заканчивается выселением. В Интернете периодически доносятся истории о сносе построек ${ }^{1}$ или отказе в регистрации земельного участка, но из-за нелегальности «родовых поместий» их присутствие и их нужды зачастую оказываются невидимыми. Метафора «неолоколониализма» или колонизации оказывается в данном случае проблематичной, хотя и позволяет показать процессы власти и дискурсивного доминирования.

\section{Взаимоотношения с местной властью}

В отличие от инвайроменталистских движений, экопоселения, как правило, не выступают против государства и бизнеса. Скорее они создают параллельные структуры самоуправления в условиях сложившегося социального порядка. Это движение «олицетворяет практическую политику “сделай сам”, политику “да”» (Liftin 2012: 131). Конечно, российские поселения значительно отличаются от европейских, их жители куда более консервативны и с опасением относятся к гендерным вопросам, процессам глобализации и демократии. Они мало интересуются проблемами прав человека и мирового неравенства, точнее, не готовы говорить о них в таких терминах. Но они также настроены на то, чтобы все делать самим, не ожидая никакой помощи от государства и местной власти в частности:

«У нас как-то был глава администраџии. Дома прям. Так получилось, зашел, и он говорит: «Ребята, я вообще, я восхищаюсь такими людьми, которые вот так вот город бросают, чтобы жить на природе, и которые живут не вот так, - он сказал, - а вот так» [показывает руками]. То есть, ну, мы все сами делаем. Дороги сами делаем, мы ничего не выпрашиваем. Ну, то есть... как-то $N$ взаимодействовал с администрацией волости, они сами помогли, чем могли, остальное мы. Своими возможностями. Это так... вполне посильно» (ПМА 2019, жен., около 40 лет).

Их позиция заключается в том, что необходимо научиться общаться даже с недружелюбным окружением - на уровне соседей, местной власти и государства в целом, - подстраиваться под них, уважать их локальный опыт и знания:

«Вот, ну, и наши...И я всем, кто приезжает, всегда с самого начала говорила: «Bbl, - говорю, - только самое главное поймите, что вот нам здесь, ну, как-то надо ладить все равно. Может, они в чем-то вначале и не правы. Уступите. Они здесь местные, они здесь старожиль». У нас же в городе ходят же, что Питер, что Москва: «Понаехали!» А сейчас в данный момент мь для них «понаехали». И нам здесь надо аккуратненько [смеется]» (ПМА 2019, жен., 51 год).

В любом случае идти напролом, «бороться с машиной» бессмысленно, лучше с ней дружить:

\footnotetext{
${ }^{1}$ Например, история о сносе дома на Урале (Кто разрушает Россию?).
} 
«Вот мне никто не мешает ... <... $>$ Ни правительство, ни партия, ни, собственно говоря, администрачия. Ну, если кто-то что-то даже вот и противится, например, ну это просто, значит, ну, недостаточно поговорили, недостаточно объяснили. И всегда есть какие-то рычаги. Ну то есть все равно сльишат, видят. Вот... вот правда, если даже вот говорить о... о нашем вот этом движении, очень много вообще всяких вот и слухов, и разговоров было» (ПМА 2019, жен., 51 год).

Анастасийцы держатся в стороне от государства и государственной власти, при этом ратуют за принятие закона о родовых поместьях, согласно которому каждый может бесплатно получить участок земли не менее одного гектара. Поселенцы ожидают государственной поддержки в первую очередь для легализации «родовых поместий», именно для этого и была создана «Родная партия». Но если за принятие закона выступают все анастасийцы, то вступать в «Родную партию» уже многие отказываются, опять же из-за недоверия государственной машине (Позаненко 2016: 148) и отсутствия заинтересованности в политических процессах. Поэтому неудивительно, что созданная в 2014 г. партия в 2020 г. была ликвидирована. Если на первоначальном этапе кто-то готов был заниматься сбором подписей и хождением по инстанциям, то позднее энтузиазм быстро угас, возникли конфликты среди поселенцев и партийных лидеров (Самохин 2021). Несмотря на политическую лояльность и стремление уходить от конфликтных ситуаций, многие жители родовых поместий не желают подчиняться требованиям государственной системы, которые касаются практик родовспоможения, вакцинации, образования, захоронения и т.п.

\section{Заключение}

В процессе взаимодействия с сельским населением становятся заметны разные идеологические основы «коренных» и «пришлых». Старые и новые жители села, как правило, четко выделяют друг друга и противопоставляют «своих» «чужим». Сельчанам не видны и непонятны разнообразные мотивы переезда, для них все переехавшие - единое сообщество. Несмотря на постоянные контакты, смешения между двумя этими категориями обычно не происходит, они существуют в параллельных реальностях и не стремятся к сближению. Конечно, жители родовых поместий преподносят локальную историю, краеведение и местные достопримечательности как плюсы выбранной ими земли и даже могут задействовать их, предлагая этно- или эко-туризм, но не такой капитал является основой их переселенческой идеологии. Они частично встраиваются в имеющиеся инфраструктуры, но при этом связи внутри поселения и с аналогичными проектами вовне плотнее, чем с соседями в селе.

\section{Источники и материалы}

Кто разрушает Россию? - Кто разрушает Россию? Сайт «Владимир Мегре». 16.02.2018 https://vmegre.com/events/38759/

ПМА - полевые материалы автора, 2009-2019 гг.

Презентация поселений 2021 - XII Круг поселений Родовых поместий. 20.02.2021 [3] Презентации поселений https://www.youtube.com/watch?v=r9Q04jF9fTU\&t=1554s

Самохин 2021 - XII Круг поселений Родовых поместий. 21.02.2021 [5] Муз. зарядка, А. Самохин «Родная партия» https://www.youtube.com/watch?v=GuKZ39SINHI

Статистика количества поселений - Статистика количества поселений. Сайт «Поселения. 
py». http://poselenia.ru/statistic/poselenia-count

\section{Научная литература}

Аверкиева К.В., Нефедова Т.Г. Дачная «колонизация» российской глубинки. Пример Костромской области // Мир России. 2016. №1. С. 103-128.

Андреева Ю.О. Представления о народных традициях в движении «Звенящие кедры России» // Аспекты будущего по этнографическим и фольклорным материалам: Сб. науч. ст. Отв. ред. Т.Б. Щепанская. СПб.: МАЭ РАН, 2012. С. 231-246.

Андреева Ю.О. «Творить рай на земле»: культ земли и природы в новом религиозном движении «Анастасия» // Изобретение религии: десекуляризация в постсоветском контексте / науч. ред. Ж. В. Кормина, А. А. Панченко, С. А. Штырков. СПб.: ЕУСПб, 2015. С. 163-185.

Аничкова О.М. Потомственные и «новые» крестьяне Псковской области // Новые российские гуманитарные исследования. 2018. Т. 13. http://www.nrgumis.ru/articles/archive/2018-13/novyekrestyane-rossii-sotsioantropologicheskoe-i-etnokulturnoe-issledovanie-zhiznennykh-strategiy-s

Бауман 3. Текучая современность. СПб.: Питер, 2008.

Демидова Ю.А. Коллективизм и индивидуализм в сообществах родовых поместий на примере двух экологических поселений Центральной России. // Исторический журнал: научные исследования. 2020. № 5. С. 26-41. DOI: 10.7256/2454-0609.2020.5.34131. URL: https://nbpublish.com/library_read_article.php?id=34131

Манчестер Л. Сельские матушки и поповны как «агенты просвещения» в российской деревне: позднеимперский период // Там, внутри. Практики внутренней колонизации в культурной истории России: Сб. статей / Под ред. А. Эткинда, Д. Уффельманна, И. Кукулина. М.: НЛО, 2012. С. 311-348.

Мельникова Е.A. Биографии переезда из города в деревню и риторика самотрансформации в современной России // Этнографическое обозрение. 2020. №6. С. 88-105.

Нефедова Т.Г., Покровский Н.Е., Трейвиш А.И. Урбанизация, дезурбанизация и сельско-городские сообщества в условиях роста горизонтальной мобильности // Социологические исследования. 2015. №12. С. 60-69.

Ожиганова A. Дети New Age: утопический проект движения «Анастасия» («Звенящие кедры России») // Государство, религия, церковь в России и за рубежом. 2015. №2 (33). С. 262-286.

Позаненко А.А. Самоизолирующиеся сообщества. Социальная структура поселений родовых поместий // Мир России: Социология, этнология. 2016. Т. 25. № 1. С. 129-153.

Эткинд А., Уффельманн Д., Кукулин И. Внутренняя колонизация России: между практикой и воображением // Там, внутри. Практики внутренней колонизации в культурной истории России: Сб. статей / Под ред. А. Эткинда, Д. Уффельманна, И. Кукулина. М.: НЛО, 2012. С. 6-50.

Liftin K. A Whole New Way of Life: Ecovillages and the Revitalization of Deep Community // The Localization Reader: Adapting to the Coming Downshift. Edited by Raymond de Young, Thomas Princen. Cambridge, London: The MIT Press, 2012. P. 129-140.

Sassen S. The Global City: Strategic Site, New Frontier // Ferro L., Smagacz-Poziemska M., Gómez M., Kurtenbach S., Pereira P., Villalón J. (eds). Moving Cities - Contested Views on Urban Life. Wiesbaden: Springer VS, 2018. P. 11-28.

\section{References}

Andreeva, J.O. 2012. Predstavleniia o narodnykh traditsiiakh v dvizhenii “Zveniashchie kedry Rossii" [Images of folk traditions in Ringing Cedars of Russia movement]. In Aspekty budushchego po etnograficheskim i fol'klornym materialam [Aspects of future on ethnographic and folklore materials], ed. by T.B. Shchepanskaia, 231-246. St. Petersburg: MAE RAN.

Andreeva, J.O. 2015. “Tvorit' rai na zemle”: kul't zemli i prirody v novom religioznom dvizhenii "Anastasiia" ["Create paradise on the land": cult of earth and nature in new religious movement Anastasia]. In Izobretenie religii: desekuliarizatsiia v postsovetskom kontekste [Invention of re- 
ligion: desecularization in post-Soviet context], ed. by J.V. Kormina, A.A. Panchenko, and S.A. Shtyrkov, 163-185. St. Petersburg: European University Saint Petersburg.

Anichkova, O.M. 2018. Potomstvennye i "novye" krest'iane Pskovskoi oblasti [Hereditary and "new" peasants of the Pskov region]. Novye rossiiskie gumanitarnye issledovaniia 13. http:// www.nrgumis.ru/articles/2028/

Averkieva, K.V., and T.G. Nefedova. 2016. Dachnaia "kolonizatsiia" rossiiskoi glubinki. Primer Kostromskoi oblasti [Dacha "colonization" of the Russian hinterland. An example of the Kostroma region]. Mir Rossii 1: 103-128.

Bauman, Z. 2008. Tekuchaia sovremennost' [Liquid modernity]. St. Petersburg: Piter.

Demidova, Yu.A. 2020. Kollektivizm i individualizm v soobshchestvakh rodovykh pomestii na primere dvukh ekologicheskikh poselenii Tsentral'noi Rossii [Collectivism and individualism in the communities of kin's domains on the example of two ecological settlements in Central Russia]. Istoricheskii zhurnal: nauchnye issledovaniia 5: 26-41. DOI: 10.7256/24540609.2020.5.34131.

Etkind, A., D. Uffel'mann, and I. Kukulin. 2012. Vnutrenniaia kolonizatsiia Rossii: mezhdu praktikoi i voobrazheniem [Internal colonization of Russia: between practice and imagination]. In Tam, vnutri. Praktiki vnutrennei kolonizatsii v kul'turnoi istorii Rossii: Sbornik statei [There, inside. Internal Colonization Practices in the Cultural History of Russia: Collection of Articles], ed. by A. Etkind, D. Uffel'mann, and I. Kukulin, 6-50. Moscow: NLO.

Liftin, K. 2012. A Whole New Way of Life: Ecovillages and the Revitalization of Deep Community. In The Localization Reader: Adapting to the Coming Downshift, ed. by R. de Young, T. Princen, 129-140. Cambridge, London: The MIT Press.

Manchester, L. 2012. Sel'skie matushki i popovny kak "agenty prosveshcheniia" v rossiiskoi derevne: pozdneimperskii period [Rural priest's wives and daughters as "agents of enlightenment" in the Russian countryside: the late imperial period]. In Tam, vnutri. Praktiki vnutrennei kolonizatsii v kul'turnoi istorii Rossii: Sbornik statei [There, inside. Internal Colonization Practices in the Cultural History of Russia: Collection of Articles], ed. by A. Etkind, D. Uffel'mann, and I. Kukulin, 311-348. Moscow: NLO.

Mel'nikova, E.A. 2020. Biografii pereezda iz goroda $v$ derevniu i ritorika samotransformatsii $\mathrm{v}$ sovremennoi Rossii [Biographies of moving from city to village and the rhetoric of selftransformation in modern Russia]. Etnograficheskoe obozrenie 6: 88-105.

Nefedova, T.G., N.E. Pokrovskii, and A.I. Treivish. 2015. Urbanizatsiia, dezurbanizatsiia i sel'sko-gorodskie soobshchestva $\mathrm{v}$ usloviiakh rosta gorizontal'noi mobil'nosti [Urbanization, de-urbanization and rural-urban communities in the face of increasing horizontal mobility]. Sotsiologicheskie issledovaniia 12: 60-69.

Ozhiganova, A. 2015. Deti New Age: utopicheskii proekt dvizheniia “Anastasiia” (“Zveniashchie kedry Rossii") [Children of New Age: the utopian project of the "Anastasia" movement ("The Ringing Cedars of Russia")]. Gosudarstvo, religiia, tserkov'v Rossii i za rubezhom 2 (33): 262-286.

Pozanenko, A.A. 2016. Samoizoliruiushchiesia soobshchestva. Sotsial'naia struktura poselenii rodovykh pomestii [Self-isolated communities. The Social structure of kin's domain settlements]. Mir Rossii: Sotsiologiia, etnologiia 1 (25): 129-153.

Sassen, S. 2018. The Global City: Strategic Site, New Frontier. In Moving Cities - Contested Views on Urban Life. Ed. by L. Ferro, M. Smagacz-Poziemska, M. Gómez, S. Kurtenbach, P. Pereira, J. Villalón, 11-28. Wiesbaden: Springer VS. 